\title{
The Role Of The Great Silk Road In The Formation, Development And Support Of Interethnic And Intercultural Dialogue And Exchange
}

\author{
Mamasalieva Guldona Anvarbekovna \\ Lecturer Of The Department Of World History Of Andijan State University, Andizhan Region, \\ Republic Of Uzbekistan
}

Journal Website:

http://usajournalshub.c

om/index,php/tajssei

Copyright: Original

content from this work

may be used under the

terms of the creative

commons attributes

4.0 licence.

\section{ABSTRACT}

The article examines the role of the Great Silk Road in the formation, development and maintenance of interethnic and intercultural relations with other peoples in the context of trade and economic relations. This article attempts to reveal the role of the Great Silk Road as the main and important trans-European highway, which has contributed to the improvement of cultural ties over the years.

\section{KEYWORDS}

The Great Silk Road, TRANS- Eurasian highway, Trade and Economic relations, Interethnic dialogue, Cultural exchange.

\section{INTRODUCTION}

The Great Silk Road as an extensive international trade route that united a whole system of trade communications, which was actively functioning from the second half of the 2nd century $B C$ to the end of the 15th century $A D$. had a huge impact on the formation of the political, economic and cultural structure of many countries through which he passed.

It was a vast historical and cultural space with many routes, where not only caravans moved, but people, ideas, material and spiritual values moved, civilizations were formed. At different stages of history, its branches, the volume and nature of transported goods, subjects and objects of relations changed, but its role as a certain factor in the historical development of different peoples and countries was always clearly traced.

The study highlights and describes the characteristic features of the Great Silk Road, in the process of formation and improvement of the culture of peoples. A special role in this direction was played by caravan roads, in 
particular, the Great Silk Road, which in ancient times connected such states as China, India, Central Asia, the Middle and Near East, the Mediterranean, promoting interethnic and intercultural relations in them. As a result of these established ties, many countries have shown a tendency towards rapprochement and gradual unification of cultural components. As we can see, on the threshold of the third millennium, mankind is faced with the need to look for new ways. In light of this concept, an important role is assigned to the Great Silk Road in the establishment and revival of closer cultural and economic contacts between numerous peoples. It proves that only close cooperation and mutual enrichment of cultures is the basis of peace and progress for all mankind. Many people think that the name of the Great Silk Road is associated with the precious commodity at that time - silk. But it would be unfair to reduce the significance of the Great Silk Road exclusively to the silk trade. Its role was much broader and more varied, because caravans not only with various goods passed through it, but also spiritual values and religious ideas penetrated. And also the Great Silk Road was a road of ethnic migration. Of particular note is the powerful stream of religious and philosophical views that were broadcast along the Silk Road. Close intercultural contacts led to the creation of original works of art, in which various cultural traditions were manifested. Today it is quite obvious that each of the more or less significant shopping centers located on the routes of the Silk Road was not only an intermediary in the movement of goods, but also a kind of mediator in the communication of numerous nations and nationalities.

\section{METHODS}

Since ancient times, the development of human civilization is inextricably linked with the formation of transport corridors. One of the most significant achievements in the history of world civilization is the Great Silk Road.

The Silk Road is a system of caravan routes that have linked the cultural centers of the vast continent between China and the Mediterranean for over a thousand years. The term itself was first introduced into scientific circulation in the 70s of the XIX century by the German geographer and geologist F.P. Richthofen. Later, he received a broader interpretation and began to denote the entire complex of trade contacts $[2,7]$.

The beginning of the functioning of the Great Silk Road dates back to the second half of the 2nd century BC, when the diplomat and intelligence officer Zhang Jiang first opened the Western region, the countries of Central Asia, for the Chinese. Thus, as it were, two great roads were connected into one whole. One, going from the West from the Mediterranean countries to Central Asia, the other, leading from the East from the Han Empire to Central Asia [10,11].

We can say that the Great Silk Road is a grandiose trade route that connected East and West and became the reason for the emergence of many unique cities, historical monuments, customs and traditions, as well as states. Numerous data, including archaeological data, indicate that trade routes served to ensure the full functioning of society by satisfying the need for raw materials and all kinds of goods. The Great Silk Road is also no exception to these spoken words. The name 
"silk" is, of course, conditional, since not only silk but also other goods were traded along this route. The list of all goods transported along the Great Silk Road is not exhaustive. These are myrrh, incense, jasmine water, abra, cardamom, nutmeg, ginseng, python bile, carpets, linens, dyes, minerals, diamonds, jasper, amber, corals, ivory, silver, gold, furs, coins and much more. ... They also carried thoroughbred horses, horses, camels and elephants and other animals. Cultivated plants also spread along the Silk Road: grapes, peaches and others. But silk remained the main trade item, which, along with gold, turned into an international currency. From the 2nd century $A D$, silk became the main commodity that Chinese merchants carried to distant countries. Lightweight, compact and therefore especially convenient for transportation, the latter attracted the attention of buyers along the entire route of the caravans, despite the obvious high cost. It was highly regarded in East Turkestan and Central Asia, India and Parthia, Rome and Alexandria. So, the Egyptian queen Cleopatra loved luxurious robes made of this material, in the first centuries A.D. in Rome there was a special market for the sale of silk, and the Visigoth king Alaric, during the siege of this city in 408, demanded from the local residents 4 thousand silk tunics as a ransom [2.5]. All this indicates that it is thanks to the Silk Road that people have the opportunity to develop interethnic and intercultural communications, along which international communication went from the extreme reaches of Asia to the countries of the West.

Also, this unique path served as a conduit for various innovations, including in art (dance, music, fine arts, architecture), religion (Christianity, Buddhism, Islam, Manichaeism), technology (the very production of silk, as well as gunpowder, paper, etc. ). In addition, knowledge about astronomy, pharmacology, sugar refining, and the production of household items from silver and gold have spread. Various types of art were exchanged between the two regions, for example: lutes, harps, flutes and the Tashkent dance "hutenu" ("western jumping dance") [3,6669]. Also, the influence of the Silk Road has greatly contributed to the retransmission of technological advances such as papermaking technology, pig iron smelting technology and land irrigation technology $[13,38]$.

The length of the path was 12 thousand kilometers [10,17] and not all merchants passed the entire road completely. In order to preserve security and increase effective trade along the Great Silk Road in cities and villages through which merchants passed, caravanserais were created (and cities arose on the basis of caravanserais), where it was possible to exchange, wholesale goods and, most importantly, find out the latest commercial news [5,229].

On the way of the caravans, rich cities, trade and craft settlements began to appear and flourish. Among these cities, such cities as Malan (Merv) in Turkestan, Ango (Bukhara), Kango (Samarkand) in Uzbekistan, (Darus) Taraz in Kazakhstan, Suyab, Balasagun (Tokmak), Davan (Uzgen) in Kyrgyzstan stood out $[13,40]$. There is no doubt that these cities along the Silk Road turned from trade centers to scientific and cultural centers, leaving their large mark on the history of civilizations. The cities formed here served as a bridge for establishing closer cultural and economic contacts, improving relationships between people inhabiting these great 
settlements and cities. After some time, these cities will be visited, as Chinese and GrecoRoman sources say, trade caravans and diplomatic embassies. So, the given data is also proof that in the unification of peoples precisely in the cultural and interethnic plan, a great role belongs to the settlements and cities that existed along the Great Silk Road, which were the conductors of both the one and the other side.

Stronger intercultural relations between West and East have served some nations and nationalities. They fully, without noticing themselves, turned into bearers of elements of everyday life, traditions and culture of their countries and became ambassadors of goodwill and missionaries of spirituality in various states of the world. For example, the Sogdians can be cited. This people made the most tangible contribution to the civilizational development of the regions of the world. They mainly settled on the territory of Samarkand, Bukhara, Ferghana, Khujog and formed their own association Sogd, the most remarkable, at all times Sogdian merchants traded along the entire Silk Road route. The fact is that the homeland of the Sogdians was located in the center of the Silk Road and, due to its geographical location, was a kind of mediator $[9,101]$. It seems that the significance of the Great Silk Road is much broader and more multifaceted. The Great Silk Road is not just a trade artery, even if it is a transit and extensive one, but an established and centuries-old communication of countries, peoples and civilizations with inevitable borrowings in various fields of science, culture and technology $[4,96]$. Of course, this wonderful trade route contributed to the spread of goods, art and technology, the development of intercivilizational and interfaith contacts between the peoples of Europe and Asia, their mutual understanding and cultural mutual enrichment.

Thus, the role of the Great Silk Road in the development and maintenance of interethnic and intercultural dialogue and cultural exchange is unpredictable, in addition, it played a great role in the interchange of earthly civilizations, in expanding and strengthening friendship between the peoples of the whole world. From this we can conclude that the heritage of the Silk Road had an undoubted impact on the very formation of the world.

\section{RESULTS AND DISCUSSIONS}

The Great Silk Road represents one of the most precious heritage in human history. It was he who had a deep and comprehensive influence on the history and civilization of the peoples of Eurasia. The fact is that different peoples living along the Silk Road were at different levels of intellectual, cultural and economic development. Thanks to trading operations, they visited various cities, got acquainted with the business, cultural and economic life of other peoples, buying their goods, they saw, and then adopted their material and spiritual values. Especially science, art, literature, crafts, as well as technology spread among the peoples who found themselves in the sphere of action of the Great Silk Road. It can be stated that the influence of the Silk Road on civilizational development was so multifaceted that to a greater extent, most tangibly it affected the process of urbanization, the emergence of cities, their economic, business and cultural life $[13,39]$. Thus, all the achievements broadcast through the Great Silk Road in space of time and different parts of the world 
were perceived by all peoples, adapted and, acquiring peculiar unique features, became common property.

So the idea is substantiated that the Great Silk Road, creating the basis for mutual exchange between East and West, united different peoples. This road, which connected distant Europe with Asia, propelled humanity to amazing achievements, having a positive impact on the trade of developed countries, on the development of branches of science and cultural exchange.

The issues of interethnic and intercultural dialogue have been extremely important at all times. The centuries-old intercultural interaction of peoples thanks to the Great Silk Road was an attribute, an integral part of globalization, interstate integration and cooperation. A special emphasis in the relevance of intercultural dialogue is given to the content and diversity of the "collection" of cultures, traditions and customs. In this understanding, the role of the Great Silk Road was to preserve, maintain and develop each culture.

The end of the twentieth century is characterized by changes in the world that are unique in terms of geopolitical significance and scale. The whole world is becoming an integral and interdependent system. The 21st century will obviously be the century of globalization in international relations. In these conditions, the process of integration of states must be viewed not only as a historical inevitability, but also as a powerful factor of stability, stability and peace. One of the indispensable conditions for the development of peoples is an active exchange of information between peoples and civilizations. Achievements of cultural dialogue were spread through contacts through trade, conquest, resettlement. Whole cultural layers were transplanted onto fertile soil, and a new cycle of development began here. The main role in this process was played by the Great Silk Road, linking East and West $[6,82]$.

We all know well that the most wonderful way of contacts and communication between peoples is the path of trade and science. That is why the process of restoring the traditions of the Great Silk Road has become relevant in the 21st century, given its role in the development and maintenance of cultural exchange on a global scale. According to the World Tourism Organization (UNWTO), the Great Silk Road is the longest route in the world. It covers Europe, Asia, Africa and connects three oceans: the Pacific, Indian and Atlantic. The route passes through the territory of countries whose area is 55.4 million square kilometers, or $43 \%$ of the Earth's land area, with a population of 4.7 billion people [1,12]. The study of this material will make it possible to introduce the words of B.Ya. Stavisky that the Great Silk Road is the first transcontinental route for the exchange of goods and cultural achievements in the history of mankind $[11,2]$. These spoken words confirmed that in 1993 at the UN General Assembly a decision was made to revive the Great Silk Road as an important channel of international cooperation in the field of diplomacy, culture, science, trade and tourism.

Now we can conclude that the search for ways to rationally combine the values of traditional culture and mentality of peoples with the processes of modernization requires serious scientific understanding in the interests of preserving and maintaining states 
and peoples of their national and cultural identity while simultaneously integrating into global processes.

\section{CONCLUSION}

The history of the legendary Silk Road is full of mysteries and secrets. Here ancient civilizations arose and disappeared, new ethnic groups arose and whole peoples perished as a result of invasions of invaders. Unknown craftsmen created priceless cultural monuments, famous travelers made amazing discoveries. In general, this Transcontinental route had a huge impact on the entire world civilization. Although this path began to disappear already in the 16th century, its research does not stop today. It attracts the attention of many countries who want to travel around it, both to explore the roots of its history and to understand its role in the international community. Thus began a wide and comprehensive study of this path. It was from this moment that the role of the Great Silk Road increased as the most important channel for interaction of cultural, economic, and tourism ties in the world. Today, in the age of integration, an individual state cannot develop without cooperation with other countries. From this we can summarize that if the Silk Road in ancient times was the main route for trade in goods, then now it has acquired a new meaning and content, and its role in the formation and development of states contributed to the prosperity of many peoples of the world.

\section{REFERENCES}

1. Alexandrova A.N., Kolesnikova M.E., Dmitriev V.A., Kudryavtsev A.A. Historical and cultural heritage of the Great Silk Road and promotion of tourist distances.
Materials of the International Scientific and Practical Conference. Stavropol, 2016.

2. Akhmetshin N. Kh. Secrets of the Silk Road. Moscow, 2002.

3. Barfield T. S. The Perilious Frontier: Nomadic Empires and China 221 B.C to AD 1757 / T. S Barfield. - Edition Unstated edition, 1992.

4. Jerusalem A.A. To the interpretation of the main routes of the Great Silk Road // Formation and development of the routes of the Great Silk Road in Central Asia in ancient times and in the Middle Ages. Tashkent, 1990.

5. History of the peoples of Uzbekistan. 1 volume / Ch. ed. K. V. Trever. Tashkent, 1950. - 229 p. 6

6. Kobzeva OP, Mukhammedzhanov AR The Great Silk Road and the World Civilization (Study guide). Tashkent, 2002.

7. Kuzmina E.G. Prehistory of the Great Silk Road. Dialogue of cultures Europe-Asia. Moscow, 2010.

8. Mamleva LA Formation of the Great Silk Road in the system of transcivilizational interaction of the peoples of Eurasia // Vita Antiqua. 1999. No. 2.- Access mode:

9. http // archeology. kiev.ua/pub/mamleyeva.h)tm.

10. Mirzaev RS The role and significance of transport communications of the Silk Road in modern international relations: dis. ... Candidate of Polit. Sciences: 23.00.04 / R.S. Mirzaev. Moscow, 2005.

11. Rtveladze E. The Great Silk Road. Encyclopedic Reference: Antiquity and the Early Middle Ages. Tashkent, 1999.

12. Stavisky B.Ya. The Great Silk Road - the first transcontinental route in the history of mankind for the exchange of goods 
and cultural achievements // Formation and development of the routes of the Great Silk Road in Central Asia in antiquity and the Middle Ages. Tashkent, 1990.

13. Radkevich V.A. The Great Silk Road. Moscow, 1990.

14. "National Research Tomsk Polytechnic University". Tutorial. "The Great Silk Road: history and modernity." Tomsk 2017.http // istgeografy.moy.su / index / territorry- aproach 0-5. 